ORIGINAL ARTICLE

\title{
Compare the Outcomes of Subcutaneous Drains versus No Drains in Patients with Repeated Cesarean Section
}

\author{
AESHA SADAF RIZWAN ${ }^{1}$, BUSHRA MEHMOOD ${ }^{2}$, SHAHZADI HANNAN ARSHAD ${ }^{3}$ \\ ${ }^{1}$ Assistant Professor of Obstetrics \& Gynecology, Shahida Islam Medical College Lodhran \\ ${ }^{2}$ Assistant Professor of Obstetrics \& Gynecology, Shahida Islam Medical College Lodhran \\ ${ }^{3}$ House Officer, Shaikh Zayed Hospital Lahore \\ Corresponding Author: Bushra Mehmood, Assistant Professor of Obstetrics \& Gynecology, Shahida Islam Medical College Lodhran. \\ Email, bushramehmood214@gmail.com. Contact \#+92 3346058341
}

\begin{abstract}
Objective: The aim of this study is to compare the outcomes of subcutaneous drains versus no drains in patients with repeated cesarean section.

Study Design: Randomized control trial

Place and Duration: Conducted at Gyne \& Obs Department, Shahida Islam Teaching Hospital Lodhran, during from 8-01-2020 to 8-08-2020.

Methods: Total 90 pregnant women with repeated cesarean section were presented in this study. Patients were aged between 22-50 years. Detailed demographics of enrolled cases including age, body mass index, gestational age and parity were recorded after taking informed written consent. Patients were categorized into two groups, group I had 45 patients with subcutaneous drain and 45 patients of group II were without drain. Post-operative outcomes were assessed and compared among both groups. VAS was used to compare pain among both groups. SPSS 22.0 version was used to analyze the data.

Results: Mean age of the patient in group I was $30.6 \pm 8.44$ years with mean BMI $33.08 \pm 5.26 \mathrm{~kg} / \mathrm{m}^{2}$ but in group II mean age was $29.03 \pm 7.37$ years with mean BMl $31.12 \pm 11.58 \mathrm{~kg} / \mathrm{m}^{2}$. Mean gestational age in group I was $37.9 \pm 3.9$ weeks and in group II mean gestational age was $37.3 \pm 2.7$ weeks. There was no any significantly difference in parity among both groups. Post-operative mean haemoglobin in group I was lower $7.9 \pm 1.6 \mathrm{gm} \%$ as compared to group II $8.11 \pm 0.4 \mathrm{gm} \%$. Mean pain score in group I was $6.8 \pm 4.7$ and in group II was $8.2 \pm 4.11$. Prevalence of wound infection was greater in group II $5(11.1 \%)$ as compared to group I $3(6.7 \%)$. Hospital stay was shorter in group I 9.7 \pm 2.11 days as compared to group II 10.8 \pm 1.14 days. Frequency of superficial SSI and wound seroma were significantly higher among patients of group II.

Conclusion: In this study we concluded that those patients who received subcutaneous drain undergoing cesarean section resulted low post-operative pain with fewer chances of wound infection as compared to the patients undergoing C-section without drain. Except this frequency of SSI and hospital stay was shorter among patients of drain group.

Keywords: Cesarean, Drain, Wound Infection, Superficial Surgical Site Infection, Pregnant Women
\end{abstract}

\section{INTRODUCTION}

Cesarean section (CS) is one of the most common operational procedures performed in modern obstetrics [1]. Despite that, surgical techniques and stages do widely differ [2]. These variances depend on various aspects, which include surgeon's preferences, patient's features, and available facilities and circumstances [3]. One of the most prevalent complications of CS is superficial surgical site problems, including sepsis, seroma development, and collapse [4].

One of the popular, yet questionable, techniques in CS is the insertion of a subcutaneous drain for the wound. The advantage of such a method is that any blood or serous fluid that may develop in the subcutaneous region which causes postoperative pain or provides a rich substrate for microbial growth and infection, can be drained [5]. Thus, it is hypothesized that drains can lessen the burden of surgical site infection. Some surgeons, however, have generated much controversy concerning the utility of subcutaneous drains [5].

Postoperative problems include: superficial infections, dehiscence, or the existence of a fluid reservoir (seroma and hematoma) at the wound site. The following symptoms worry 3 to 15 percent of women after a caesarean section $[6,7]$ and often result in prolonged hospitalization, antibiotic medication, thereby leading to increased postpartum care expenses. A superficial infection is part of a surgical site infection (SSI) which, according to the Centers for Disease Control and Prevention (CDC), is an infection that occurs within 30 days of the conducted surgical procedure. The risk factors for the above complications include young age at childbirth, smoking, obesity, arterial hypertension, diabetes, chorioamnionitis, increased intrapartum blood loss, prolonged ruptured of membrane, emergency caesarean section and subsequent surgical delivery, use of suboptimal antibiotic prophylaxis, improper preparation of the surgical field, extended duration of the surgical procedure, and the employed caesarean section technique, including that of the incision and of the suturing of the skin [8-11].

Recently, Yamasato et al [12] reported that the rates of wound dehiscence tend to increase as the body mass index (BMI) increases. Two decades ago, Walters et al [13] revealed that the mean period of wound healing for a disturbed abdominal incision is 15 days, when the surgical debridement and drainage is effective, 67 days when the process is not successful and 23 days when the wound is re-sutured. Given the enormous numbers of CS performed worldwide, any preventive strategies that could potentially help to lower the frequency of wound complications would 
have a considerable influence on national economic health programs.

In 2004, Anderson and Gates [14] published the latest meta-analysis examining the impact of subcutaneous tissue closure on wound complication rates following CS. The authors included seven randomised controlled trials (RCTs) that comprised 2056 women and concluded that the risk of wound haematoma, seroma or any consequence was reduced when subcutaneous tissue closure was conducted. 10 Since then, however, additional trials have been published in the field and an update of current research is required to establish definitive conclusions.

The purpose of this study is to compare the outcomes of subcutaneous drains versus no drains in patients with repeated cesarean section.

\section{MATERIAL AND METHODS}

This randomized control trial was conducted at Gyne \& Obs Department, Shahida Islam Teaching Hospital Lodhran, during from 8-01-2020 to 8-08-2020 and comprised of 90 patients. Detailed demographics of enrolled cases included age, body mass index, gestational age and parity were recorded after taking informed written consent. Patients below 22 years age, had intraoperative complications and those did not give written consent were excluded from this study.

Patients were aged between 22-50 years. . Patients were categorized into two groups, group I had 45 patients with subcutaneous drain and 45 patients of group II were without drain. Women in the research had a modest transverse incision made in their skin. Dissection with a razor-sharp blade was always the next step. A C-shaped incision was used to access the lower uterine section. Controlled cord traction is used to deliver the fetus, placenta, and membranes. Number 1 delayed absorbable polyglatin (Vicryl) stitches are used to close the uterine incision in two layers. The peritoneal visceral and parietal layers are open. Number 1 continuous delayed absorbable polyglatin (Vicryl) sutures were used to seal the rectus sheath. Number $2 / 0$ interrupted delayed absorbable polyglatin (Vicryl) sutures were used to seal the subcutaneous fat in both groups of women. Nonabsorbable 2-0 silk mattress sutures were used to seal the wound. Females in group I were given an infant feeding tube that was manually fenestrated (4-5 fenestrae) using scissors and then removed from the skin through a $2 \mathrm{~cm}$ lateral opening to one of the wound angles. a 10cc syringe vacuum was established and the drain sewn to the skin for 48 hours before being removed. Post-operative outcomes were assessed and compared among both groups. VAS was used to compare pain among both groups. SPSS 22.0 version was used to analyze the data.

\section{RESULTS}

Mean age of the patient in group I was $30.6 \pm 8.44$ years with mean BMI $33.08 \pm 5.26 \mathrm{~kg} / \mathrm{m}^{2}$ but in group II mean age was $29.03 \pm 7.37$ years with mean BMI $31.12 \pm 11.58 \mathrm{~kg} / \mathrm{m}^{2}$. Mean gestational age in group I was $37.9 \pm 3.9$ weeks and in group II mean gestational age was $37.3 \pm 2.7$ weeks. There was no any significantly difference in parity among both groups. (table 1)
Table 1: Baseline details of enrolled women

\begin{tabular}{|l|l|l|}
\hline Variables & $\begin{array}{l}\text { Group I } \\
(\mathbf{n}=\mathbf{4 5})\end{array}$ & $\begin{array}{l}\text { Group II } \\
(\mathbf{n}=\mathbf{4 5})\end{array}$ \\
\hline Mean age (years) & $30.6 \pm 8.44$ & $29.03 \pm 7.37$ \\
\hline Mean BMl (kg/m ${ }^{2}$ ) & $33.08 \pm 5.26$ & $31.12 \pm 11.58$ \\
\hline Mean gestational age (weeks) & $37.9 \pm 3.9$ & $37.3 \pm 2.7$ \\
\hline Mean Parity & $1.08 \pm 2.4$ & $1.06 \pm 2.8$ \\
\hline
\end{tabular}

Post-operative mean haemoglobin in group I was lower $7.9 \pm 1.6 \mathrm{gm} \%$ as compared to group II $8.11 \pm 0.4 \mathrm{gm} \%$. Mean pain score in group I was $6.8 \pm 4.7$ and in group II was 8.2 \pm 4.11 . (Table 2)

Table 2: Post-operative comparison of pain and haemoglobin among groups

\begin{tabular}{|l|l|l|}
\hline Variables & $\begin{array}{l}\text { Group I } \\
(\mathbf{n}=\mathbf{4 5})\end{array}$ & $\begin{array}{l}\text { Group II } \\
(\mathbf{n}=\mathbf{4 5})\end{array}$ \\
\hline Mean pain score & $6.8 \pm 4.7$ & $8.2 \pm 4.11$ \\
\hline Mean haemoglobin (gm\%) & $7.9 \pm 1.6$ & $8.11 \pm 0.4$ \\
\hline
\end{tabular}

Prevalence of wound infection was greater in group II 5 (11.1\%) as compared to group I $3(6.7 \%)$. Hospital stay was shorter in group I $9.7 \pm 2.11$ days as compared to group II 10.8 \pm 1.14 days. (Table 3 )

Table 3: Comparison of hospital stay and wound infection

\begin{tabular}{|l|l|l|}
\hline Variables & Group I (n=45) & $\begin{array}{l}\text { Group II } \\
(\mathbf{n}=\mathbf{4 5})\end{array}$ \\
\hline Mean Hospital Stay (days) & $9.7 \pm 2.11$ & II 10.8 \\
\hline Wound Infection & $3(6.7 \%)$ & $5(11.1 \%)$ \\
\hline Yes & $42(93.3 \%)$ & $40(88.9 \%)$ \\
\hline No
\end{tabular}

Frequency of superficial SSI, superficial breakdown, fever and wound seroma were significantly higher among patients of group II. (Table 4)

Table 4: Post-operative complications among both groups

\begin{tabular}{|l|l|l|}
\hline Variables & Group I (n=45) & Group II (n=45) \\
\hline Superficial SSI & $3(6.7 \%)$ & $5(11.1 \%)$ \\
\hline Superficial breakdown & $4(8.9 \%)$ & $7(15.6 \%)$ \\
\hline Fever & $5(11.1 \%)$ & $7(15.6 \%)$ \\
\hline Wound seroma & $4(8.9 \%)$ & $12(26.7 \%)$ \\
\hline
\end{tabular}

\section{DISCUSSION}

Performing appropriate surgical techniques to avoid problems from cesarean delivery is extremely important in a time when cesarean delivery rates are on the rise [3]. Even though prophylactic drain placement to prevent wound complications is contentious, studies that have investigated its effectiveness in this scenario have found inconsistent results [4].

In this prospective study 90 women were presented undergoing cesarean section. Patients were categorized into two groups, group I had 45 patients with subcutaneous drain and 45 patients of group II were without drain. Mean age of the patient in group I was $30.6 \pm 8.44$ years with mean BMI $33.08 \pm 5.26 \mathrm{~kg} / \mathrm{m}^{2}$ but in group II mean age was $29.03 \pm 7.37$ years with mean BMI $31.12 \pm 11.58 \mathrm{~kg} / \mathrm{m}^{2}$. Our findings were comparable to the previous studies $[15,16]$. Mean gestational age in group I was $37.9 \pm 3.9$ weeks and in group II mean gestational age was $37.3 \pm 2.7$ weeks. There was no any significantly difference in parity among both groups. It was the goal of Khalifa et al. [17] to assess the effects of routine subcutaneous drain versus no drain on wound complications in women with diabetes and obesity 
in their randomized controlled study, which included 170 women. The drain group's mean BMl was $34.1 \mathrm{~kg} / \mathrm{m} 2$, while the no drain group's was $34.2 \mathrm{~kg} / \mathrm{m} 2(P=0.1)$. The effect of subcutaneous stitch closure versus subcutaneous drain to avoid wound rupture after cesarean delivery was compared in a randomized controlled research on 590 women by Magann et al. [3]. Drain group's mean BMI was $40.7 \mathrm{~kg} / \mathrm{m} 2$, while drain group's was $39.4 \mathrm{~kg} / \mathrm{m} 2(P=0.39)$. [3]. It was reported that no wound complications occurred in obese women who had cesarean deliveries when subcutaneous tissue approximation was used alone or in combination with a drain in the study by Ramsey et al. [18]. The drain group's mean BMI was $48.4 \mathrm{~kg} / \mathrm{m} 2$, while the no drain group's was $45.0 \mathrm{~kg} / \mathrm{m} 2(P=0.019)$ [18].

In current study post-operative mean haemoglobin in group I was lower $7.9 \pm 1.6 \mathrm{gm} \%$ as compared to group II $8.11 \pm 0.4 \mathrm{gm} \%$. Mean pain score in group I was $6.8 \pm 4.7$ and in group II was $8.2 \pm 4$.1. Prevalence of wound infection was greater in group II $5(11.1 \%)$ as compared to group I 3 (6.7\%). Hospital stay was shorter in group I 9.7 \pm 2.11 days as compared to group II $10.8 \pm 1.14$ days. The CAESAR study collaboration group evaluated the efficacy of alternate surgical procedures in women undergoing cesarean section, including liberal versus restricted use of drains, and found that the use of a subcutaneous drain in cesarean section significantly reduced post-operative pain. $[19,20]$ A study conducted by Kumar in 2004 came to the same conclusion. [21] The VAS was employed in the Kumar and CAESAR investigations as a semi-objective technique for evaluating pain. Frequency of superficial SSI, superficial breakdown, fever and wound seroma were significantly higher among patients of group II in our study.

\section{CONCLUSION}

In this study we concluded that those patients who received subcutaneous drain undergoing cesarean section resulted low post-operative pain with fewer chances of wound infection as compared to the patients undergoing C-section without drain. Except this frequency of SSI and hospital stay was shorter among patients of drain group.

\section{REFERENCE}

1. Gad MS, Abd MM, Sttar E, Abd AM, Gayed E, Mahmoud NF. Evaluation of lower segment cesarean section scar by sonography. Menouf Med J 2015; 28:873-878.

2. Hofmeyr GJ, Mathai M, Shah AN, Novikova N. Techniques for caesarean section. Cochrane Database Syst Rev 2008; 1:CD004662.

3. Magann EF, Chauhan SP, Rodts-Palenik S, Bufkin L, Martin JN, Morrison JC. Subcutaneous stitch closure versus subcutaneous drain to prevent wound disruption after cesarean delivery: a randomized clinical trial. Am J Obstet Gynecol 2002; 186:1119-1123.

4. Tully L, Gates S, Brocklehurst P, McKenzie-McHarg K, Ayers $S$. Surgical techniques used during caesarean section operations: results of a national survey of practice in the UK. Eur J Obstet Gynecol Reprod Biol. 2002; 102:120-126.

5. Gates S, Anderson ER. Wound drainage for caesarean section. Cochrane Database Syst Rev 2013; 13:CD004549.

6. Conner, S.N.; Verticchio, J.C.; Tuuli, M.G.; Odibo, A.O.; Macones, G.A.; Cahill, A.G. Maternal Obesity and Risk of Postcesarean Wound Complications. Am. J. Perinatol. 2014, 31, 299-304.

7. Temming, L.A.; Raghuraman, N.; Carter, E.B.; Stout, M.J.; Rampersad, R.M.; Macones, G.A.; Cahill, A.G.; Tuuli, M.G. Impact of Evidence-Based Interventions on Wound Complications after Cesarean Delivery. Am. J. Obstet. Gynecol. 2017, 217, 449.e1-449.e9.

8. Salim, R.; Braverman, M.; Teitler, N.; Berkovic, I.; Suliman, A.; Shalev, E. Risk Factors for Infection Following Cesarean Delivery: An Interventional Study. J. Matern. Fetal Neonatal. Med. 2012, 25, 2708-2712.

9. Conroy, K.; Koenig, A.F.; Yu, Y.H.; Courtney, A.; Lee, H.J.; Norwitz, E.R. Infectious Morbidity after Cesarean Delivery: 10 Strategies to Reduce Risk. Rev. Obstet. Gynecol. 2012, 5, 69-77.

10. Mackeen, A.D.; Schuster, M.; Berghella, V. Suture versus Staples for Skin Closure after Cesarean: A Metaanalysis. Am. J. Obstet. Gynecol. 2015, 212, 621.e1-621.e10.

11. Kawakita, T.; Landy, H.J. Surgical Site Infections after Cesarean Delivery: Epidemiology, Prevention and Treatment. Matern. Health Neonatol. Perinatol. 2017, 3, 12.

12. Yamasato $\mathrm{K}$, Yoshino $\mathrm{K}$, Chang $\mathrm{AL}$, Caughey $\mathrm{AB}$, Tsai PJ. Cesarean delivery complications in women with morbid obesity. J MaternFetal Neonatal Med 2016;23:1-4.

13. Walters MD, Dombroski RA, Davidson SA, Mandel PC, Gibbs RS. Reclosure of disrupted abdominal incisions. Obstet Gynecol 1990;76:597-602.

14. Anderson ER, Gates $S$. Techniques and materials for closure of the abdominal wall in caesarean section. Cochrane Database Syst Rev 2004;(4):CD004663

15. Bindal J, Munda G. A clinical study to compare drain versus no drain in post cesarean section. Int $\mathrm{J}$ Reprod Contracept Obstet Gynecol 2017;6:3903-6.

16. Kawakita T, Landy HJ. Surgical site infections after cesarean delivery: epidemiology, prevention and treatment. Matern Health Neonatol Perinatol. 2017;3:12. Published 2017 Jul 5. doi:10.1186/s40748-017-0051-3

17. Khalifa AAA, Abdelrazak KM, Abdelazim IA. Routine subcutaneous drain versus no drain in cesarean section for diabetic obese women: a randomized controlled trial. Int $J$ Curr Microbiol Appl Sci 2015; 4:479-485.

18. Ramsey PS, White AM, Guinn DA, Lu GC, Ramin SM, Davies $\mathrm{JK}$, et al. Subcutaneous tissue reapproximation, alone or in combination with drain, in obese women undergoing cesarean delivery. Obstet Gynecol 2005; 105(Part 1):967973.

19. Enkin MW. Closed suction wound drainage at caesarean section. Cochrane Database Syst Rev. 1995:(2).

20. Brocklehurst P, Quigley M, Ayers S, Juszczak E. Caesarean section surgical techniques: a randomised factorial trial (CAESAR). BJOG. 2010;117(11):1366-76.

21. Kumar SA. Subcutaneous drain versus subcutaneous stitch closure to prevent wound disruption after cesarean section. J. Obstet. Gynecol. India. 2004;54(3):237-42 